\title{
RESPONSIBILITIES OF THE LEGAL REPRESENTATIVES IN THE FACE OF TAX OFFENCES AND PENALTIES
}

\author{
KANUNİ TEMSİLCILERİN VERGİ SUÇ VE CEZALARI KARŞISINDAKİ \\ SORUMLULUKLARI
}

\begin{abstract}
Sedat APAK ${ }^{1}$ ID
Abstract

The institution of legal representation, the relevant provisions of the tax procedure law and other laws taken as detailed in the terms that it contains; the responsibility of legal representatives, the legal representative of small and limited responsibility and the responsibility of the legal representatives of legal persons in two groups in order to be evaluated. Providing the convenience of collecting the tax intended to assure that moving forward with tax administration and tax would receive, in case of failure to pay tax "secondary responsibility of the context" tax and penalties in the case of legal representative name of the primarily responsible tax collection from the charge completion or obtained from references.
\end{abstract}

Keywords: Tax liability, Tax penalty, Legal representative, Tax responsibilities, Tax payers

GEL Classification:H20, H24, H25, K34.

\section{$\ddot{O} z$}

Kanuni temsil müessesesi, Vergi Usul Kanununun ilgili hükümlerinde ve diğer hüküm içeren kanunlarda ayrıntılı olarak ele alındığında; kanuni temsilcilerin sorumluluğu, "küçük ve kısıtlıların kanuni temsilcilerinin sorumluluğu" ve "tüzel kişilerin kanuni temsilcilerinin sorumluluğu" olmak üzere iki alt grupta değerlendirildiği görülmektedir. Vergiyi toplamada kolaylık sağlanması ve vergi alacağını güvence altına alma amaçlarıyla hareket eden vergi idaresi, verginin ödenmemesi durumunda "sorumluluğun ikincilliği" bağlamında vergi aslı ve cezalarını öncelikle yükümlüden alma yoluna gitmekte, ancak alınamaması durumunda kanuni temsilci olan vergi sorumlusundan tamamlama ya da tahsil etme hallerine başvurmaktadır. Bununla ilgili değerlendirmeler, makalede ayrıntılı olarak işlenmeye çalışılmış durumdadır.

Anahtar Kelimeler: Vergi borcu ,Vergi cezası, Kanuni temsilci, Vergi sorumlusu,Vergi yükümlüsü

JEL Sinıflandırmasi:H20, H24, H25, K34.

\footnotetext{
${ }^{1}$ Doç. Dr., İstanbul Üniversitesi Siyasal Bilgiler Fakültesi, Siyaset Bilimi ve Kamu Yönetimi Bölümü, Hukuk Bilimleri Anabilim Dalı, apak_sedat@yahoo.com
} 


\section{INTRODUCTION}

Usually Tax Responsible and Concept of Tax Responsibility which is created to facilitate tax collection or to secure tax lien, is responsible against Treasury, which is one of the parties related to the taxation and tax assessment that the state imposes to cover public expenditures, rather than Taxpayer and Tax Responsible is become responsible against Treasury and Tax Administration for material and formal tax payments instead of Taxpayer.

Within the context of aforementioned legal relationship, tax related and legal sanctions which the legal representatives face when they failed to fulfil their tax related responsibilities, how the responsibilities of tax responsible and tax payer are arranged, and what future actions these relationships may lead is the main writing objective of our article.

In this article, we will first define the concepts of tax responsible and tax responsibility and from these definitions we will try to investigate various situations legal representatives against tax related penalties and sanctions.

\section{METHOD}

The method to be used in this article will be firstly referred to as tax liability and later on as tax liability explanations of legal representatives. In the second paragraph of the eighth article of the Tax Procedure Law, Tax Responsible is defined as "the person who is addressed by the claimant tax office in terms of tax payment" and in accordance with this general expression, the tax responsible can be defined as the person who fulfils all the formal and material obligations including levying, notification, accrual and collection stages of taxation according to the tax related laws, on behalf of taxpayer. (Öner, 2016, s. 62)

In other words, the tax responsible is the person who is addressed by the tax office for the occurrence of taxable events and completion of material and formal payments and in even some conditions, tax responsible is the one who pays the defined tax debt from his own financial resources by replacing the original tax debtor or in case of solidary obligation, who is held responsible to fulfil the both formal and material obligations related to taxation on behalf of somebody else. (Öner, 2016, s. 62)

It is clear that in the explanation of Tax Responsible at the eighth article of the Tax Procedure Law, is a general, undetailed expression, However the definitions stated there represents other obligations which are stated in the other articles of Tax procedure law such as bordereau preparation, book keeping, submitting tax statements, make conciliation application, period of limitation, litigation. (Öner, 2016, s. 62)

Especially in the fourth paragraph of the eight article of the Tax Procedure Law, the expression of "the definition of taxpayer that is defined in pursuant articles of this Law is applicable to Tax Responsible" is a very clear expression that shows that tax responsible is equally responsible as the taxpayer in legal terms according to us. (Arslan, 2012, s. 57)

In Ninth Article of the Tax Procedure Law related to tax liability, it is stated that if the minors and wards and those who are classified as noncompos mentis become taxpayers, the obligations of these person's will be fulfilled by their parents, guardians or trustees in the capacity of legal representative. (Öner, 2016, s. 62)

In the introduction part of this article; it was mentioned that a very general definition was made in the Tax Procedure law and afterwards it was mentioned that tax responsible is obliged with many and variable obligation which are defined in various laws. Now, when we desire to look these obligations more systematically and as a resource; 
Tax Responsible's obligations and liabilities are stated in legal terms at the 11th article of the Tax Procedure Law with the phrase "those who are obliged to pay taxes on the payments they made are responsible for the complete assessment and payment of the tax and other duties related to the assessed tax", and in 94th article of Revenue Law and 15th and 30th Article of Corporate Tax law, 17th Article of Law of Inheritance and Succession Tax and 19th Article of Stamp tax Law (Kırbaş, 2015, s. 76)

When the cases stated in law occurred; the legislator assumes that the legal representatives are responsible for paying taxes and/or penalties from their property, either directly by substituting the taxpayer or become jointly responsible with the taxpayer together, and in this point, "joint liability", in other words double liability model is adopted related to fulfilment of obligations and payment of taxes. There are also other areas of tax liability, such as

"Responsibility of Inheritors", "Responsibility of Certified Public Accountants and Financial Advisor's", and "Responsibility of Those who employed Professionals without official record card" (Öner, 2016, s. 82,83. Kırbaş, 2015, s. 76, 77, 78. Şenyüz, D.ve diğerleri,2014, s. 79$85)$

In addition, as it can be understood, point of importance in the context of tax liability is the fact that the concept of tax liability is predominantly "collective" or "joint". As it is known in joint responsibility, tax liability is the obligation of the taxpayer that include payment of the taxes to the tax office or submitting the tax statement and this transactions bear the qualification of "simple joint responsibility" or "accessory joint responsibility".(Öner, 2016, s. 63) If the responsibility is accessory, that means the tax responsible will not addressed before the taxpayer and with this arrangement, the tax payer and tax responsible will not be pressured at the same time, the debt is first requested from taxpayer and if the debt cannot be collected from taxpayer then it will be requested from tax responsible.(Öner, 2016,s. 63) It is clear that the preference to request the debt from tax payer rather than tax responsible includes a deviation relatively, in this way tax lien can be only demanded from tax responsible who is responsible for the accrual of the tax only at the second stage. (Öner, 2016, s. 63)

Now, after this point, we will first give information about the way of authorization of Legal Representatives related to taxation and then we will continue our investigation with responsibilities and liabilities of the same legal representatives against the tax related offences and sanctions.

\section{FINDINGS}

The term Representation means that a person with capacity to act on behalf of another person according to the will of the represented person or requirement of law and can make the one who he/she represented a debt or right holder.(Arslan,2012, s. 60, Öner,2016, s. 66) If the authority of representation is based on a law, this form of representation is called legal representation, and the person with such authority is called a "legal representative". If the authority of representation is based on the will of the person who is represented, this form of representation is called voluntary representation, and the person with such authority is called a "voluntary representative".(Öner, 2016, s. 66)

The term real person means, of course, a human being and according to the tax laws, a person is eligible to be tax payer with birth. The material and formal obligations and payments of the taxpayer who do not have the legal capacity to act are fulfilled by his/her legal representatives, with law the legal representative, who is called parent, guardian or trustee in that case, has become person who is responsible for the tax. (Şenyüz, 2014, s. 82)

When legal entities, minors and wards or corporations which are not legal entities become tax responsible, the obligation of these are fulfilled by legal representatives of these and in cases 
of foundations or sects which do not have legal entities, the obligation of these are fulfilled by those who are administrating these entities or their representatives according to the 10th article of Tax Procedure Law and 35th article of Law on Collection Procedures of Assets. (Kırbaş, 2015, s. 77)

Legal entities are represented by legal organs authorized to represent themselves, and these bodies may sometimes be single persons or sometimes organized in the form of a board and the organ which is authorized to represent legal entity may assign the authority of representation to a person or a group within the executive board within the extent permitted by law, regulation and agreements, where the person or groups bearing tax liability are bodies with the legal representation authority and may also vary according to the nature of their formation. (Şenyüz, 2014, s. 83)

The legal representative of the legal entities is executive board in joint stock companies, the manager of the company in the limited companies, acting partners in the limited partnerships, executive board in cooperatives and all of the partners in general partnerships; and according to the provisions of the Commercial Code, in joint stock companies, representation authority can be assigned to manager or executive director with the condition that at least one member of the executive board will have the representation authority; in limited companies, the representation authority of the company can be assigned to one or more partners with condition that the partner who have the representation authority will carry the title of company manager according to the provision of the articles of incorporation. (Kırbaş, 2015, s. 77)

As is known, a joint-stock company is represented by a executive board, which may be appointed by a contract or it may consist one or more members elected by the general assembly, and it is essential that board members are fully competent. (Şenyüz, 2016, s. 362)

In this part of the article so far, along with tax responsibilities and types, we have tried to explain the subject of eligibility to become a legal representative, which is a sub expansion of our major subject. In the following sections of the article, the situation of legal representatives against the tax related offence and sanctions as real persons and legal entities will be considered.

\section{DISCUSSIONS}

\section{STATUS OF REAL PERSON (MINOR AND WARD) LEGAL REPRESENTATIVES AGAINST TAX SANCTIONS}

According to the Tax Procedure Law; since legal capacity is required for both tax obligation and tax liability, it is possible that the minor and ward can be a tax payer and tax responsible but the obligation and duties belong to these individuals, will be fulfilled by legal representatives in accordance with the provisions of Article 10 of the Tax Procedure Law.(Karakoç,2007,s.200, Arslan, 2012, s. 60, Kalenderoğlu, 2016, s. 38,39.)

If the legal representatives do not fulfil their duties, tax debts will be primarily requested from the original obligor, who represented minor and ward and if the debt cannot be collected from the taxpayer, the debt will be collected from legal representative. Of course; the legal representative reserves the right to claim the debt he/she paid from the taxpayer.(Kalenderoğlu,2016. s. 39)

In the Tax Procedure Law, in punishments imposed related to tax related liabilities of individuals who are under custody and guardianship and the person's that the administration of their business is assigned to a trustee, occurred as a result of unlawful conduct of parents, 
guardians and trustees, the addressee of the punishment will the legal representatives, not the minor or wards. (Şenyüz,2016. s. 356)

However, it should be noted that, unlike legal entity representation, the tax related receivables, that is to say, tax penalty, late fee and interest of default will directly requested from legal representative and the representative will not be able to claim the amounts he/she paid from the person who he/she represented. (Kalenderoğlu, 2016, s. 40)

If the conclusion related to the legal representatives of real persons is desired to be stated clearly; if a legal representative is a representative of a minor or a ward, the original amount of unpaid tax will be requested from tax payer at first, if these amount cannot collected from taxpayer, these amount will be requested from legal representative and later legal representative can claim the amount he/she paid from the tax payer.( Öner,2016, s. 68)

In the case of interest of default and late fee which is related to unpaid tax; first this amount will be collected from the taxpayer and if these amount cannot be collected from taxpayer, the legal representative will be obliged to pay these amount and furthermore, legal representative will not be able to claim the amount he/she paid from tax payer; if the aforementioned amount is a tax penalty or a penalty of irregularity in that case, the one who is responsible for this fine is legal representative and legal representative will not be able to claim the amount he/she paid from tax payer. (Öner, 2016, s. 68)

Another important point that needs to be addresses here is; who will be the addressee in the face of offences that impose custodial sentences. At this point, In accordance with the provisions of Article 330 of the Tax Procedure Law; the guardian, parent and trustee who committed the offence of tax evasion shall be liable to punishment irrespective of whether there is intent or negligence is present or not.

\section{STATUS OF LEGAL REPRESENTATIVES AGAINST TAX SANCTIONS IN CASE OF LEGAL ENTITIES}

Tax-related obligation for legal entities are fulfilled by their representative bodies and in principle the legal representative is manager of the company in limited companies and legal representative is the executive board in the joint-stock companies and associations. (Arslan,2012, s. 61)

If the individuals forming the representative body failed to fulfil the tax liabilities related to legal entity, the original amount of the tax is requested from legal entity, if this amount cannot be collected, tax administration will request this amount from legal representative, if legal representative pays the original amount of tax which accrued to legal entity, the legal representative can claim this amount from taxpayer naturally.(VUK md.10.(10/01/1961 tarih,10703-10705 say1lı T.C. Resmi Gazete).

According to the provisions of the Article 35 of the Law on the Collection Procedures of Assets; in the case when the individuals who are legal representatives of the legal entity or individuals who are managing the legal entity are different for the period when the Public Receivables are accrued and when the Public Receivables must be paid, both of these persons are conjointly responsible for the payment of Public Receivables. (Arslan, 2012, s. 61)

In the joint implementation related to unpaid tax debts and penalty increments which are applied to these debts, the relevant amount, is requested from legal entity first; if the legal entity is unable to pay the amount, the unpaid part of this amount will be collected from the legal representative and the legal representative will not be able to claim the amount he/she paid from the tax payer. (Öner, 2016, s. 68) 
In legal entities, legal representatives will be responsible for the custodial sentences related to tax related procedures according to personality principle in offence and punishment, and the penalty is imposed on the one who commits the offence who is generally legal representative in other words those who is responsible from the tax.(Öner, 2016, s.68, Arslan, 2012, s.61; Kalenderoğlu, 2016, s.38-39) Penalty of imprisonment s naturally cannot be imposed to a legal entity but here, the reason for the usage of the term "generally" is that in case when the one who commit the offence of tax evasion is an employer or manager of the legal entity, these person's will be put on a trial and held responsible.(Öner,2016,s.68,Arslan,2012,s.61, Kalenderoğlu,2016,s.38-39) At this point, it is necessary to punish of those who are responsible for the offence both formally and structurally, that is to say, not only the representatives but also those who are actually commit the relevant offence can be considered as wrongdoer. (Şenyüz, 2016,s. 359)

\section{CONCLUSION}

Situation of Legal representatives against tax sanctions are varied according to the fact that legal representatives are representatives of real persons or legal entities. Namely; if the legal representative is a representative of minor and ward; the tax is initially requested from the taxpayer, but in cases where it cannot be collected from taxpayer, then the tax is requested from the representatives and the tax penalties are directly requested from representatives. (Öner, 2016, s. 68)

If the legal representative, who is the representative of the legal entity, does not fulfil his/her duties in on time related to taxation, then the original amount of relevant tax is primarily requested from the legal entity, tax penalties are also requested from legal entity primarily but if these amounts cannot be collected from legal entity, these amounts will be collected from legal representative. (Öner, 2016, s. 68)

\section{SUGGESTIONS}

It can be said in general that the debt is not requested from representative until it is requested from the principal obligant according to the principle of accessory liability during the collection process of tax liability. (Öncel, Kumrulu, Çağan, 2013, s. 80)

In the case of tax evasion offences that require custodial sentences, elements of crime must be investigated and revealed and legal proceedings must be initiated against the perpetrator, who is "generally" a tax responsible or a legal representative or any other individual who commit the offense. (Öner,2016, s. 68; Şenyüz,2016, s. 359) 


\section{REFERENCES}

Arslan, M. (2012). Vergi Hukuku, $8^{\text {th }}$ edition, Bursa: MKM Yayınc1l1k.

Kalenderoğlu, M. (2016). Vergi Hukuku-Türk Vergi Sistemi, 17 $7^{\text {th }}$ edition, Ankara: Agon Yayınları.

Karakoç, Y. (2007). Genel Vergi Hukuku, $4^{\text {th }}$ edition, Ankara: Yetkin Yayınları.

Kırbaş, S. (2015). Vergi Hukuku, $20^{\text {th }}$ edition, Ankara: Siyasal Kitapevi.

Öncel, M.,Kumrulu, A.,Çağan,N. (2013). Vergi Hukuku, 22 th edition, Ankara:Turhan Yayınevi.

Öner, E. (2016). Vergi Hukuku, $7^{\text {th }}$ edition Ankara:Seçkin Yayınevi.

Şenyüz, D. (2016). Vergi Ceza Hukuku, $9^{\text {th }}$ edition, Baskı, Bursa: Ekin Yayınevi.

Şenyüz, D., Yüce, M., Gerçek, A. (2014). Vergi Hukuku, $5^{\text {th }}$ edition, Bursa: Ekin Yayınevi . 